FOLIA

Amazónica

Revista del Instituto de Investigaciones

de la Amazonía Peruana

\title{
PROBLEMS REPORTED IN THE MANAGEMENT OF FARMED Arapaima gigas IN THE PERUVIAN AND BRAZILIAN AMAZON
}

\author{
Germán Augusto MURRIETA MOREY푸 José Carlos ZUMAETA CACHIQUE; \\ Linda Lizeth FLORES VILLACORTA²; Jeffson NOBRE PEREIRA ${ }^{3}$
}

\author{
1 Instituto de Investigaciones de la Amazonía Peruana (IIAP), Laboratorio de Parasitología y Sanidad \\ Acuícola, Carretera lquitos-Nauta Km 4.5, San Juan Bautista, 0784, Iquitos, Perú. \\ Correo electrónico: germantiss1106@gmail.com \\ 2 Universidad Nacional de la Amazonía Peruana (UNAP), Sargento Lores 385, Iquitos, Perú. \\ 3 Instituto Nacional de Pesquisas da Amazônia (INPA), Av. André Araújo, 2936 - Petrópolis, Manaus, \\ Amazonas, Brazil, 69067-375. Programa de Pós-graduação em Biología de Água Doce e Pesca \\ Interior-BADPI.
}

\begin{abstract}
The present study reports three cases of problems reported on farmed Arapaima gigas in the Peruvian and Brazilian Amazon ( $\left(1^{\text {st }}\right.$ case: Jaundice disease in farmed Arapaima gigas (Schinz, 1822) in Pará, Brazil; $2^{\text {nd }}$ case: Gas bubble disease in farmed Arapaima gigas from the Peruvian amazon and $3^{\text {rd }}$ case: Mortalities caused by fights between sexually mature females of Arapaima gigas. All cases were reported during field expeditions to fish farms. The first case was reported in Para, Brazil and describes a jaundice disease caused by the consumption of contaminated food by micotoxins. The second case was reported in Iquitos, Peru and describes a «gas bubble» disease on young A. gigas caused by inadequate management and lack of acclimation when translated from a fish pond to glass aquaria and wooden boxes with shallow water. The third case is reported in Manaus, Brazil and describes a storage experiment where it was demonstrated that breeding tanks with more than one female results in fights against females and consequently the death of some specimens.
\end{abstract}

KEYWORDS: Arapaima gigas; Brazil; gas bubble disease; jaundice; Peru. 


\section{PROBLEMAS REPORTADOS EN EL MANEJO DE Arapaima gigas CULTIVADOS EN LA AMAZONÍA PERUANA Y BRASILEÑA}

\section{RESUMEN}

El presente estudio reporta tres casos de problemas reportados en Arapaima gigas cultivados en la Amazonía peruana y brasileña $\left(1^{\mathrm{r}}\right.$ caso: Ictericia en Arapaima gigas cultivados en la Amazonía peruana y brasileña; $2^{\text {do }}$ caso: Enfermedad de las burbujas gaseosas en Arapaima gigas cultivados en la Amazonía peruana y $3^{\mathrm{r}}$ caso: Mortalidades causadas por peleas entre hembras maduras sexualmente de Arapaima gigas. Todos los casos fueron reportados durante expediciones de campo a piscigranjas. El primer caso fue reportado en Pará, Brasil y describe la condición de ictericia causada por el consumo de alimento contaminado por micotoxinas. El segundo caso fue reportado en Iquitos, Perú y describe la enfermedad de las burbujas gaseosas en especímenes jóvenes de $A$. gigas causada por inadecuado manejo y falta de aclimatación al trasladar a los peces de un estanque piscícola a acuarios de vidrio y cajas de madera con poca agua. El tercer caso es reportado en Manaus, Brasil y describe un experimento en el cual se demuestra que tanques de reproducción en los cuales se colocaron más de una hembra de A. gigas son inadecuados para la crianza y reproducción de esta especie, ya que como resultado se notaron peleas entre especímenes hembras que consecuentemente llevaron a la muerte de varios ejemplares.

PALABRAS CLAVE: Arapaima gigas; Brasil; enfermedad de las burbujas gaseosas; ictericia; Perú. 


\section{INTRODUCTION}

The Arapaima gigas (Schinz, 1822) known as "pirarucu», is an osteoglossiform endemic species of the Amazon region, that inhabits the Amazon River system, the western Orinoco and the river systems of the Guianas. This fish is one of the most important species for the development of intensive fish farming in the Amazonian region, being appreciated, highly demanded and regarded as a food fish of the highest quality (Queiroz and Crampton, 1999). Despite the various obstacles encountered in its farming, its production in Brazil and Peru is been increasing each year, innovating techniques of breeding, feeding process and sanitary management (IBGE 2017).

The arapaima has a high economic potential in fish farming, both for the production of meat with a view to national and international markets, and for the production of fingerlings for exportation to different countries of the world (García-Dávila et al. 2018).

With the intensification of breeding systems, there is a need for greater knowledge about the appropriate management to provide improvement in fish health conditions, especially in the early stages of production, larviculture and fish farming. At these stages, when fish are continually exposed to adverse conditions and their immune system still does not respond properly, they become more susceptible to parasites and diseases (Tavares-Dias and Martins 2017).

Taking into consideration the importance of A. gigas as a resource for the development of the aquaculture in the Peruvian and Brazilian Amazon, the present study reports three cases of problems noticed on farmed $A$. gigas due to inadequate management during the breeding and marketing process and gives some recommendations based on the experiences and studies carried out over a period of time, for improving the aquaculture activity with this fish species.

\section{MATERIAL AND METHODS}

$1^{\text {ST }}$ CASE: JAUNDICE DISEASE IN FARMED

Arapaima gigas FROM PARÁ, BRAZIL

Nine-hundred specimens of $A$. gigas raised in a fish-pond with one hectare of dimension were daily fed with balanced diet (pellets) with $40 \%$ crude protein. Some days after offering the food, fish presented loss of appetite and change of coloration. After a couple of days, high mortalities and clinical signs of jaundice were observed on the fish.

The quality of the water of the ponds was evaluated by means of physical and chemical parameters: oxygen, $\mathrm{pH}$, temperature and ammonia. Sample collection was conducted one hour before and during the catch of the fish.

\section{$2^{\mathrm{ND}}$ CASE: GAS BUBBLE DISEASE IN FARMED}

Arapaima gigas FROM THE PERUVIAN

AMAZON

Two hundred A. gigas with $12 \pm 3 \mathrm{~cm}$ standard length were acquired from a fish farm located in the Peruvian Amazon. Fish were transported to a commercial Aquarium by using plastic bags. In the Aquarium, fish were immediately placed into wooden boxes and glass aquariums without previous acclimation.

Some days after receiving the fishes, some atypical signs and symptoms were noticed in all A. gigas. Mortalities were being reported daily. In order to determine the cause of the problem, some fish were transported to the «Laboratorio de Parasitología y Sanidad Acuícola» of the «Instituto de Investigaciones de la Amazonía Peruana» IIAP, in Iquitos-Peru. In the laboratory, signs and symptoms were observed and discussed. After the analyses, all the information 
concerning to the acquisition and management of the fish before and after the arrival to the Aquarium was requested.

Reports of people involved in the capture, transportation and conditioning of fish, revealed inadequate management of the fish. Fish were captured from a fish pond at midday, when water temperature was between 29 to $30{ }^{\circ} \mathrm{C}$. Fish were immediately placed in plastic bags and transported to the commercial Aquarium. In the Aquarium, fish were removed from the bags and placed in glass aquariums and wooden boxes filled with water of the company that was with another temperature and with physical and chemical characteristics different from the ones in the ponds before catching the fish.

$3^{\text {RD }}$ CASE: MORTALITIES CAUSED BY FIGHTS BETWEEN SEXUALLY MATURE FEMALES OF Arapaima gigas

With the purpose of evaluate the best storage density for adult Arapaima gigas for reproductive processes, male and female individuals were captured from a fish pond located in Manaus, Brazil and distributed into ten concrete tanks with $300 \mathrm{~m}^{2}$. Five treatments, each with two replicas were considered: $\mathrm{T} 1=1$ male with 1 female; $\mathrm{T} 2=2$ males with 1 female; $\mathrm{T} 3=1$ male with 2 females; $\mathrm{T} 4=2$ males with 2 females and $\mathrm{T} 5=3$ males with 3 females.

\section{RESULTS}

$1^{\text {ST }}$ CASE: JAUNDICE DISEASE IN FARMED Arapaima gigas FROM PARÁ, BRAZIL

Dead fish were analyzed, observing a yellowish pigmentation throughout the body, eyes and tongue. Additionally, a longitudinal section was made from the opening of the anus to the gills, observing the kidney, liver and gall bladder enlarged with a pale yellow colour. Analyzed fish contained a yellow ascitic fluid in their abdomen and plenty of fat which was also yellow in colour. All observed signs and symptoms revealed a typical case of jaundice affecting A. gigas (Fig. 1).

Mean values of physical and chemical parameters were: temperature $28{ }^{\circ} \mathrm{C}$, dissolved oxygen $5.19 \mathrm{mg} / \mathrm{L}$, pH 6.0 and ammonium 0.04 $\mathrm{mg} / \mathrm{L}$.

$2^{\mathrm{ND}}$ CASE: GAS BUBBLE DISEASE IN FARMED Arapaima gigas FROM THE PERUVIAN AMAZON

Arapaima gigas were diagnosed as having «gas bubble disease», with obvious large and small gas bubbles present on their heads (emphysema), irritation, swollen gill filaments and roof of the mouth, exposition of part of their gills by atrophy of the opercula and exophthalmia (Fig. 2).

$3^{\text {RD }}$ CASE: MORTALITIES CAUSED BY FIGHTS BETWEEN SEXUALLY MATURE FEMALES OF Arapaima gigas

Four days after establishing the experiment, fights were noticed in tanks with more than two females. Mortalities of females were reported in treatment 3, 4 and 5. Dead fish were retired from the tanks in order to find signs of fights and to detect the degree of sexual maturation of dead specimens. Dead specimens presented external signs such as: blows, bruises, internal bleeding and bites and wounds on the fins. All dead $A$. gigas were sexually mature females (Fig. 3).

\section{DISCUSSION}

Symptoms of intoxication by micotoxins were cited in the farmed catfish hybrid, Clarias macrocephalus (Gunther) X C. gariepinus (Burchell) farmed in Thailand. This fish was intoxicated due to the feeding of rancid chicken viscera (Pearson et al. 1994). In Brazil, there are 
no reports of jaundice in farmed fish species, so the present study constitutes the first case of jaundice reported in A. gigas and in Brazil.

According to Faria et al. (2013), for breeding tropical fish, it is recommended a temperature between $25{ }^{\circ} \mathrm{C}$ and $32{ }^{\circ} \mathrm{C}$, dissolved oxygen between 1 and $5 \mathrm{mg} / \mathrm{L}$ ), pH between 6 and 9 and ammonia with values below $0.05 \mathrm{mg} / \mathrm{L}$ ). In the present study, values of the physical and chemical parameters of the water were considered as suitable for tropical fish. In the water samples, no fungi and no cyanobacteria were detected, so the intoxication by neurotoxins and hepatotoxins produced by harmful algal bloom or poor water quality was discarded.

Another probably cause of intoxication was the food given to the A. gigas as the fish-farmer noticed the problems related, just after changing the brand of the pellets used for feeding the fish. Discarding the presence of cyanobacteria in the water of the ponds, the fish-farmer decided to send samples of the food to a laboratory for analyses and stopped to feed the A. gigas with that brand of pellets.
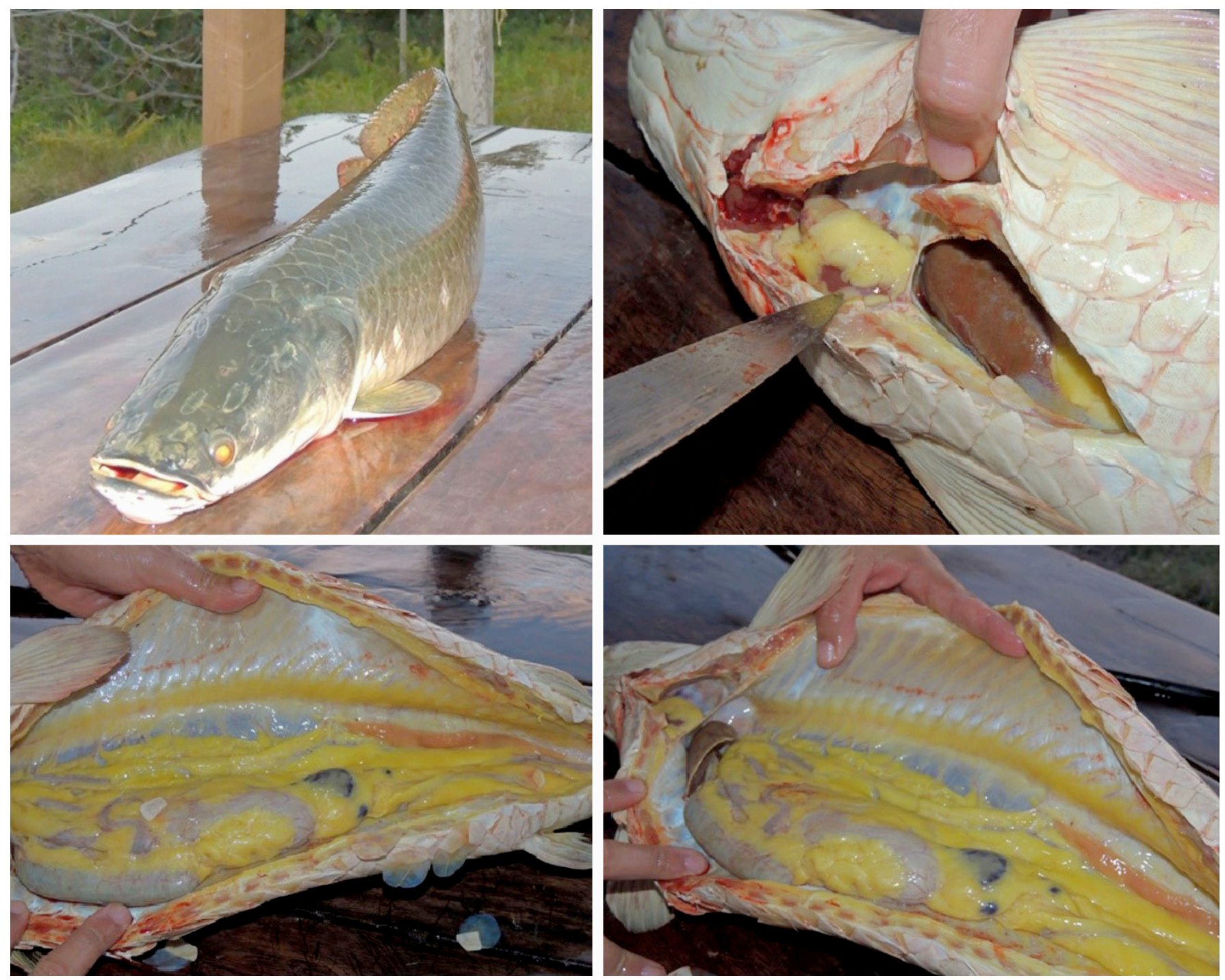

Figure 1. Specimen of Arapaima gigas (Schinz, 1822) with external signs of jaundice. B,C and D. Internal organs of A. gigas showing signs of jaundice. 

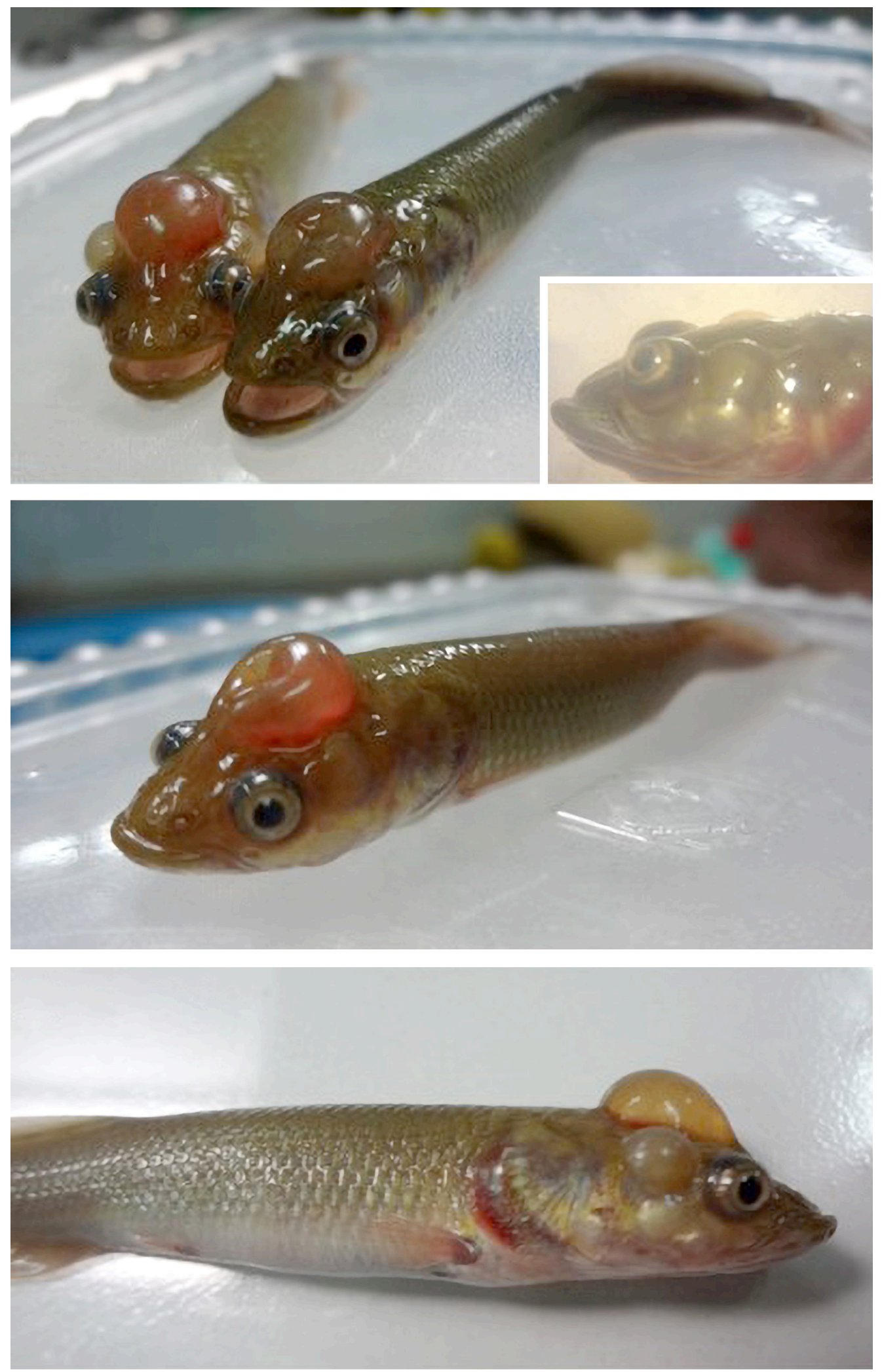

Figure 2. Gas bubble disease in Arapaima gigas (Schinz, 1822). A - D. Visible signs: emphysema, irritation, swollen gill filaments and roof of the mouth, exposition of part of their gills by atrophy of the opercula and exophthalmia. 

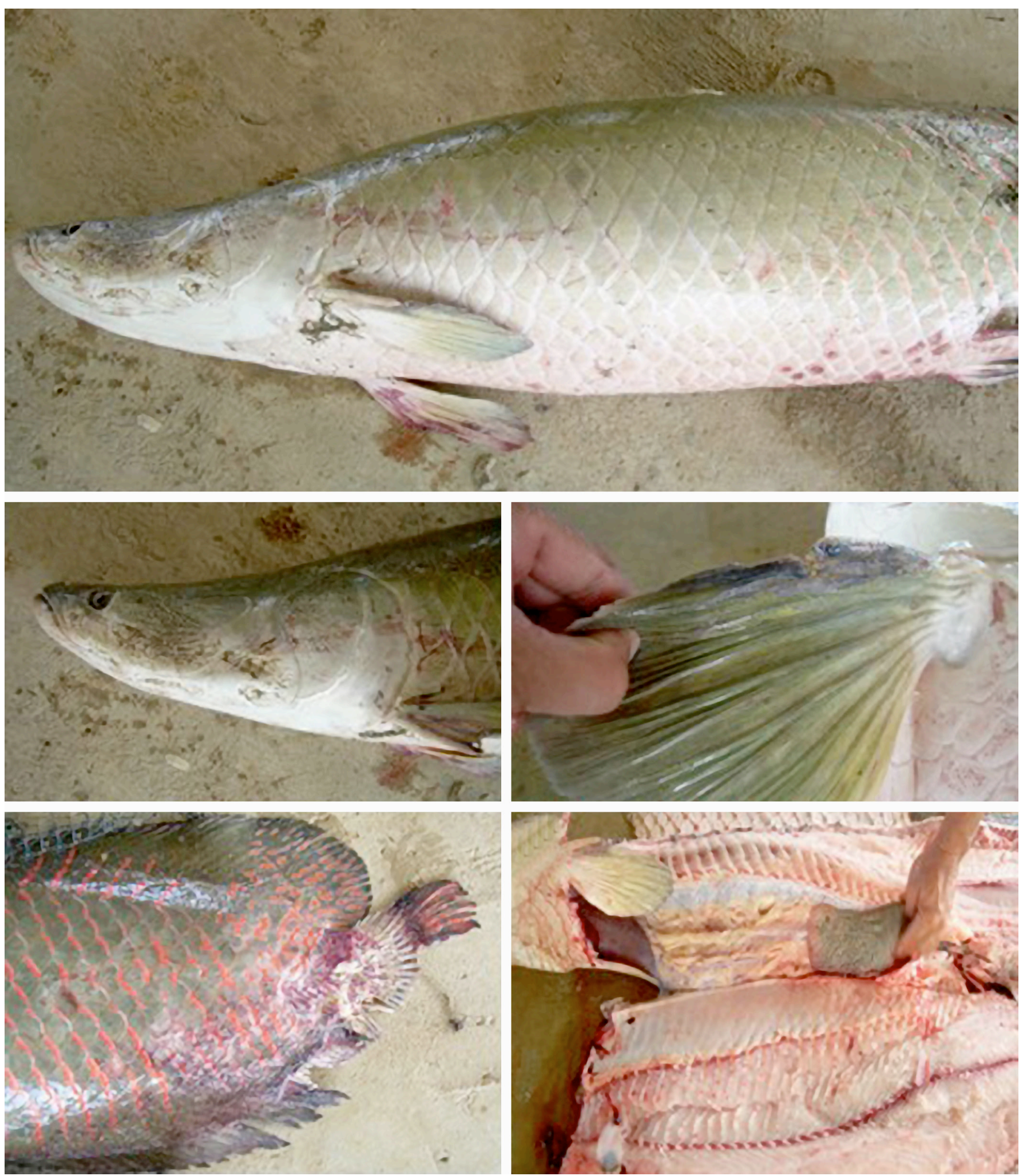

Figure 3. Specimen of Arapaima gigas (Schinz, 1822 showing wounds as a result of fights. A - B. Adult specimen with internal hemorrhage on its body, C. wound on the pectoral fin, D. wounds on caudal fin. E. Examination of internal organs, evidencing a sexually mature female specimen. 
After a week of having stopped the feeding with the alleged contaminated ration, the fish began to present improvements in their health, they presented again a normal coloration and deaths stopped. The analyses made in the laboratory showed the presence of microcystins produced by a cyanobacteria. Probably the company responsible for preparing the food contaminated some input at the time of preparation or by inadequate storage conditions.

Toxigenic fungi and bacteria can contaminate food in different stages of production and processing, from growing to transport and storage. As reported by Sabino et al. (1988), Brazil, because of its tropical climate, provides ideal conditions for the proliferation of fungi and bacteria responsible for the production of toxins. In addition, inadequate storage conditions favor fungal and bacteria growth that can contaminate the food used for fish-farmers to feed fish.

Considering the risk that the ingredients used for feeding fish or the inadequate conditions of food storing that may present high levels of toxins, as well as the lack of studies on the effects of micotoxins on fish farming, it is necessary to evaluate and monitoring the food used for fishfarmers in the fish breeding.

Susceptibility to supersaturation depends largely on whether the fish are confined to the shallow water or aquarium. Fish thatare restricted to shallow water and continuously exposed to supersaturation are the most susceptible to gas bubble disease (Bouck 1980). According to Harvey and Cooper (1962), small fish appear to be highly susceptible to gas bubble disease. A diagnostic characteristic for detecting gas bubble disease in its early stages is the manifestation of swollen roof of the mouth (Gilbert et al. 1967). In the present study case, this disease is reported in young A. gigas from aquaria and from wooden boxes with shallow water. As it was mentioned by Gilbert et al. (1967), all sick A. gigas presented a swollen roof of the mouth, confirming this characteristic as a diagnostic manifestation of the disease. Apparently, the disease was caused by a sudden change in water temperature, which provoked a descompensation in the water gases, making it supersaturated.

Death in fish suffering from gas bubble disease is apparently caused by necrosis of vital organs and tissues, probably due to anoxia resulting from capillary occlusion by gas emboli. Special methods of controlling the amount of dissolved gases in the water are required to prevent excessive mortalities in these situations (Westgard 1964). To avoid this disease, the acclimation of fish before their introduction to a new environment must be done, taking into consideration proper management and control of physical and chemical parameters in the water. Additionally, possible deficiencies in the aeration systems of pipes, aerator pumps and filters must be checked to avoid gas saturations in aquaria.

The pirarucu presents partial spawning and has peculiar reproduction habits, forming couples, selecting and isolating the spawning area, building nests and releasing eggs and sperm (Imbiriba 2001). Imbiriba (1991) reported fights between individuals of $A$. gigas, as a process of isolation of the posture area, along with the appearance of reproductive nests. In the present study case, fights, followed by deaths observed between females, clearly denoted the behavior of cut and territoriality of female A. gigas. Probably fights start when females form couples and build nests to start the reproductive process. In this way, it is recommended to keep females isolated from other females, in order to avoid fights and guarantee the success in the reproductive process under captivity for A. gigas. 


\section{ACKNOWLEDGMENTS}

We thank to the commercial aquarium AQUATRADE located in Iquitos, Peru for providing fish samples used in the reports mentioned in the second case.

\section{REFERENCES}

Bouck, G.R. 1960. Etiology of Gas Bubble Disease. Transactions of the American Fisheries Society, 109: 703-707.

Faria, R.H.S, Morais, M., Soranna, M.R.G.S., Sallum, B.W. 2013. Manual de criação de peixes em viveiro. Brasília: Codevasf, 136pp.

García C.R, Sánchez, H., Silva, F., Almendra, M., Mejia, J.E., Chávez, A., Ruiz, D.C., Estivals, G., Vásquez, A.G., Nolorbe, C.P., Dávila, G.V., Núñez, J., Mariac, C., Duponchelle, F., Renno, J-F. 2018. Peces de consumo de la Amazonía peruana. Instituto de Investigaciones de la Amazonía Peruana (IIAP), Iquitos-Perú, 218pp.

Gilbert, B., Pauley, B., Nakatani, R. 1967. Histopathology of «Gas-Bubble» Disease in Salmon fingerlings. Journal of the Fisheries Research Board of Canada, 24: 867-871.

Harvey, H.H., Cooper, A.C.1962. Origin and treatment of supersaturated river water. Intern. Pacific Salmon Fish. Comm., Progr. Rept., No.9, 1-19pp.

IBGE (Instituto Brasileiro de Geografia e Estatística). 2017. Produção da Pecuária
Municipal. Instituto Brasileiro de Geografia e Estatística, 51pp.

Imbiriba, E.P. 1991. Production and management of fingerlings pirarucu, Arapaima gigas (Cuvier). Belém: EMBRAPA-CPATU, 19pp.

Imbiriba, E.P. 2001. Creation potential pirarucu, Arapaima gigas, in captivity. Acta Amazônica, 31: 299-316.

Pearson, M.D., Chlnabutr, S., Karnchanakharn, S., Somsir, T. 1994. Jaundice disease in the farmed catfish hybrid, Clarias macrocephalus (Gunther) x C. gariepinus (Burchell), in Thailand. Journal of Fish Diseases, 17: 325-336. Queiroz, H.L., Crampton, W. 1999. A preservação e o uso sustentado dos pirarucus (Arapaima gigas, Osteoglossidae) em Mamirauá. Estratégias para manejo de recursos pesqueiros em Mamirauá. Brasília. Sociedade Civil Mamirauá, Tefé, Brasil.197pp.

Sabino, M., Lamardo, L.C.A., Inomat, G. 1988. Ocorrência de aflatoxina B1 em produtos alimentícios e rações animais, consumidos no Estado de São Paulo e em várias outras regiões do Brasil, no período de 1980 a 1987. Revista do Instituto Adolfo Lutz, 48: 81-85.

Tavares-Dias, M., Martins, M.L. 2017. An overall estimation of losses caused by diseases in the Brazilian fish farms. Journal of Parasitic Disease, 41: 913-918.

Wetsgard, R.L. 1964. Physical and biological aspects of gas-bubble disease in impounded adult chinook salmon at McNary Spawning Channel. Trans. American. Fisheries Society, 93: 306-309.

Recibido: 12 de julio de 2019 Aceptado para publicación: 27 de agosto de 2019

Esta obra está bajo una Licencia Creative Commons Atribución-NoComercial-SinDerivar 4.0 Internacional. 